\title{
Paleoenvironment and Organic Matter Accumulation Mechanism of Marine-Continental Transitional Shales: Outcrop Characterizations of the Carboniferous-Permian Strata, Ordos Basin, North China
}

\author{
Leifu Zhang ${ }^{1,2,3}{ }^{\mathbb{D}}$, Qun Zhao ${ }^{1,2,3, *}$, Sizhong Peng ${ }^{4}$, Zhen Qiu ${ }^{1,2,3}$, Congjun Feng ${ }^{4, *}$, Qin Zhang ${ }^{1,2,3}$, \\ Yuman Wang ${ }^{1,2,3}$, Dazhong Dong ${ }^{1,2,3}$ and Shangwen Zhou $1,2,3$ (D)
}

1 Research Institute of Petroleum Exploration and Development, China National Petroleum Corporation (CNPC), Beijing 100083, China; zhangleifu@petrochina.com.cn (L.Z.); qiuzhen@petrochina.com.cn (Z.Q.); zhangqin2169@petrochina.com.cn (Q.Z.); wangyuman@petrochina.com.cn (Y.W.); ddz@petrochina.com.cn (D.D.); zhousw10@petrochina.com.cn (S.Z.)

2 National Energy Shale Gas Research \& Development (Experiment) Center, Langfang 065007, China

3 CNPC Key Laboratory of Unconventional Oil and Gas, Langfang 065007, China

4 Department of Geology, Northwest University, Xi'an 710069, China; 202010337@stumail.nwu.edu.cn

* Correspondence: zhaoqun69@petrochina.com.cn (Q.Z.); fengcj@nwu.edu.cn (C.F.)

check for updates

Citation: Zhang, L.; Zhao, Q.; Peng, S.; Qiu, Z.; Feng, C.; Zhang, Q.; Wang, Y.; Dong, D.; Zhou, $S$. Paleoenvironment and Organic Matter Accumulation Mechanism of Marine-Continental Transitional Shales: Outcrop Characterizations of the Carboniferous-Permian Strata, Ordos Basin, North China. Energies 2021, 14, 7445. https://doi.org/ 10.3390/en14217445

Academic Editors: Dameng Liu and Attilio Converti

Received: 17 September 2021 Accepted: 1 November 2021 Published: 8 November 2021

Publisher's Note: MDPI stays neutral with regard to jurisdictional claims in published maps and institutional affiliations.

Copyright: () 2021 by the authors. Licensee MDPI, Basel, Switzerland. This article is an open access article distributed under the terms and conditions of the Creative Commons Attribution (CC BY) license (https:// creativecommons.org/licenses/by/ $4.0 /)$.

\begin{abstract}
In the Carboniferous-Permian period, several organic-rich black shales were deposited in a marine-continental transitional environment in the Linfen area on the eastern margin of the Ordos Basin. Integrated sedimentological and organic geochemical analyses are performed on an outcrop in order to clarify the relationship between paleoenvironment and organic matter accumulation. The results of this study show that the marine-continental transitional strata of the Upper Carboniferous Benxi Formation to Lower Permian Taiyuan and Shanxi Formation exposed in the Linfen area are composed of sandstone, shale, coal, and limestone. Total organic carbon (TOC) contents of the studied samples were mainly distributed in the range of $0.59-35.4 \%$, with an average of $7.32 \%$. From Benxi Formation to Shanxi formation, the humidity gradually increased, and the climate gradually changed from hot and humid to warm and humid during Carboniferous to Permian. The deposition of the Shanxi Formation ended with the climate returning to hot and humid, having an oxic-suboxic conditions and a high paleoproductivity. Paleoredox conditions and paleoproductivity are the two vital factors controlling the formation of organic matter in black shales. The transitional environment characterized by oxic-suboxic, relatively high deposition rate, and various source of organic matter, although different from the marine environment, provides a good material basis for the deposition of organic-rich shales.
\end{abstract}

Keywords: marine-continental transitional facies; geochemical characterization; organic matter accumulation; eastern Ordos Basin

\section{Introduction}

Unconventional resources have become an important sector in the world energy; thus, shale gas, as a vital proportion of unconventional natural gas, has drawn tremendous attention from both academia and industry [1-4]. Organic-matter-rich shales are key reservoirs for shale gas and hence have become key explorational targets in China. China's shale gas reservoirs can be classified into three types on the basis of depositional facies: marine shales, continental shales, and marine-continental transitional (transitional hereinafter) shales [5-8]. Marine shales and continental shales (mostly lacustrine facies) have been widely and systematically reported [9-18]. In contrast, studies on transitional shales, particularly paleoenvironment and organic-matter accumulation mechanism, are scarce. Transitional deposition is characterized by alternate deposition of shales, sandstones, coals, 
and limestones, resulting from rapid and frequent changes of sea level and hence frequent changes of depositional environment [19]. Consequently, shales of transitional facies are not as laterally continuous, nor as thick as shales of marine facies. Vertically, thin sandstones, limestones, and coals are usually embedded within transitional shales, forming a vertical lithological assemblage that is different from the vertically continuous marine shales ( $200 \mathrm{~m}$ thick) in the Sichuan Basin. This is attributed to the frequent variations of depositional facies, while marine shales were deposited within stable shelf environments [1]. A few authors argued that transitional shales were deposited under lagoon environment $[20,21]$, while others argued that transitional shales were dominated by prodelta and delta plain facies, and determining which sedimentary environment favors the deposition and accumulation of organic-matter-rich shales requires further research.

In the Carboniferous-Permian period, North China underwent transition from marine environment to continental environment, resulting in deposition of multiple shales horizons in the Ordos Basin. Recently, a number of new shale gas discoveries were yielded from these black shales of the Carboniferous Benxi Formation and Permian Shanxi Formation [19], suggesting promising shale gas potential of transitional deposits. Factors controlling organic matter accumulation within transitional shales remain poorly understood. In addition, natural gas was yielded from sandstones in the Permian Shanxi Formation and limestones in the Permian Taiyuan Formation. Natural gas reserved within such reservoirs are sourced from transitional shales and colas. Overall, the complex juxtaposition of different lithologies form a rather "unconventional" hydrocarbon accumulation model, in which sandstones and limestones are gas reservoir, while shales and coals are both source rock and gas reservoir, and even cap rocks when they overlie sandstone and limestone reservoirs. It forms a unique system where hydrocarbons are "self-generated", "selfaccumulated", and "self-preserved", which could provide new insights for understanding the hydrocarbon potential of transitional facies.

This study focuses on the Carboniferous-Permian strata outcropped at the eastern Ordos Basin, the Liulin city, Shanxi Province, China. Petrological, total organic carbon (TOC), major and trace elements, and other geochemical characteristics of Liulin section are analyzed. In addition, two wells located in the eastern Ordos Basin, adjacent to Liulin section, targeting the Carboniferous-Permian strata are discussed in detail [19], and their recent interpretations are also integrated. Sedimentological and geological characteristics of the wells are analyzed and compared with the Linxin outcrop. The objectives are to: (1) unravel the paleoenvironmental conditions including paleo-depositional facies, paleoclimate, paleo-water salinity, and paleo-redox conditions of the Carboniferous-Permian transitional deposition in the Ordos Basin; (2) investigate the organic-matter accumulation mechanism of transitional facies; and (3) address the unconventional shale gas accumulation model.

\section{Geological Setting}

The Ordos Basin is a cratonic basin and consists of six secondary tectonic units, including Yimeng Uplift, Western Fold-thrust Belt, Tianhuan Depression, Shanbei Slope, Jinxi Flexural Fold Belt, and Weibei Uplift [4,6,7,22-25] (Figure 1). The studied section is located in the Liulin city, Shanxi Province, eastern Ordos Basin, located in the Jinxi Flexural Fold Belt. The Ordos Basin has experienced a general evolution trend from marine to transitional to continental environment. From the Proterozoic to early Paleozoic, the Ordos Basin was submerged under seawater, depositing thick carbonates. From the Ordovician to early Carboniferous, the Caledonian movement uplifted the basin, leading to denudation of strata [22-25]. In the late Carboniferous, North China experienced continuous subsidence resulting from Hercynian movement, sea water entered the basin from the northeastern direction, and marine strata were deposited in the Ordos Basin. In the late Permian, because of collision of the late Hercynian movement, seawater was forced to recede towards the southwestern direction, and fluvio-lacustrine deposition started in the entire Ordos Basin [26]. 


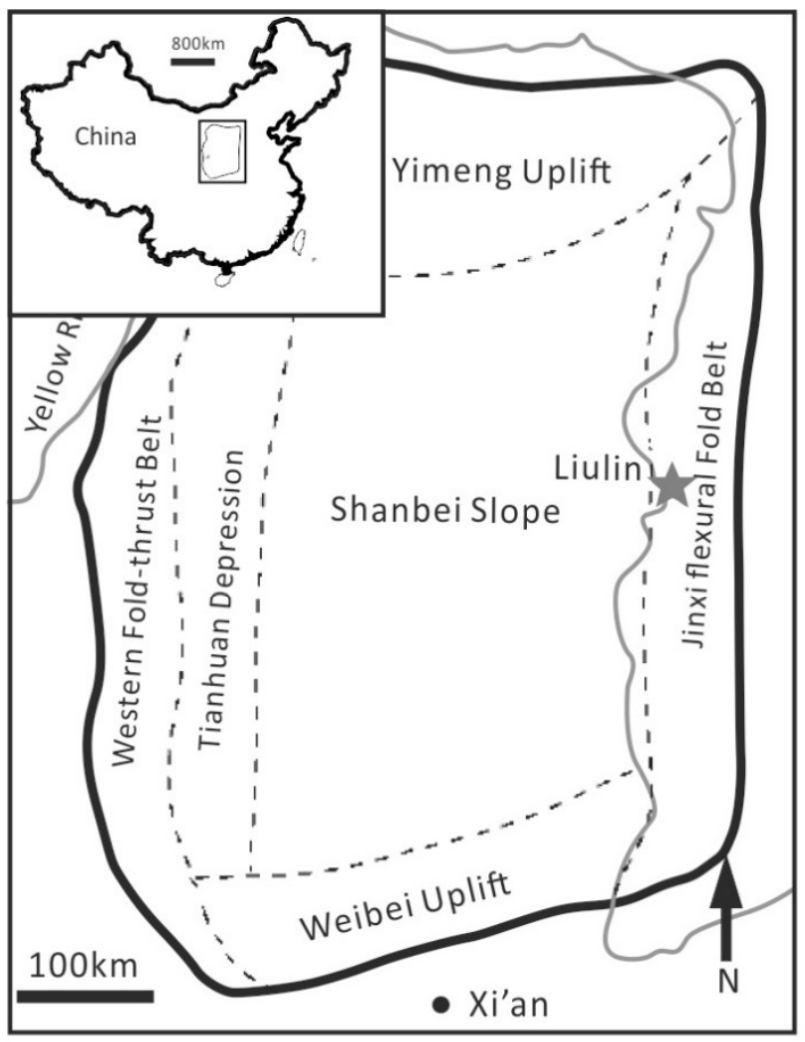

Ordos Basin boundary

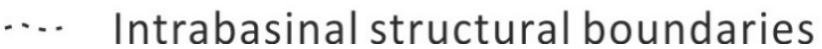

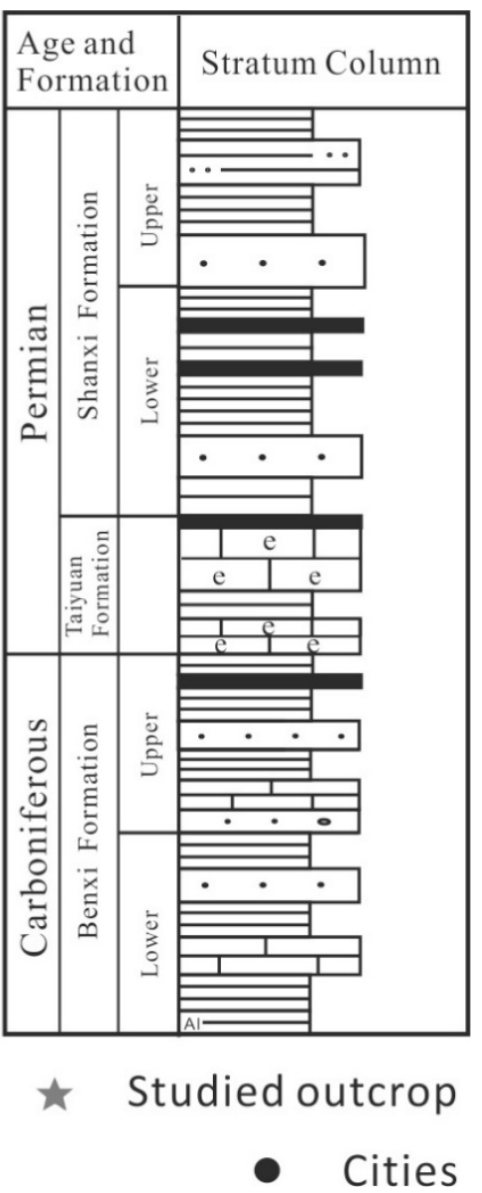

- Cities

Figure 1. Tectonic map and stratum column of the Ordos Basin and location of the study outcrop.

The Carboniferous Benxi Formation in the studied area consists of a $\sim 68 \mathrm{~m}$ thick barrier island and lagoonal deposits. The basal part is composed of limonite/hematite with nestlike structure and bauxite layers, the middle part is composed of lagoonal carbonaceous shales with interbedded siderite lenses and tidal channel sandstones, while the upper part is composed of barrier island facies sandstones, carbonaceous shales, and coals. The Carboniferous Taiyuan Formation is $\sim 54 \mathrm{~m}$ thick tidal flat-shelf deposits, consisting of grey-dark grey bioclastic calcareous limestone, interbedded with black shales, coals, and grey-light grey sandstones. The Permian Shanxi Formation is $\sim 82 \mathrm{~m}$ thick tidal flatlagoonal and delta-front facies deposits. The basal part is black shales and silty shales interbedded with coals, and the upper part is grey-greyish white sandstones and dark grey-black shales.

\section{Methods and Samples}

Samples were collected from the Chenjiazhuang village, Liulin section, Lvliang City, Shanxi Province, coordinate of E: $110^{\circ} 54^{\prime} 22.57^{\prime \prime}$, N: $37^{\circ} 33^{\prime} 27.32^{\prime \prime}$. To avoid the impact of pollution and weathering, we dug into the exposed outcrop for $10 \sim 20 \mathrm{~cm}$ and then collected fresh samples. A total of 20 samples were collected, with five samples from the Benxi Formation, five samples from the Taiyuan Formation, and ten samples from the Shanxi Formation (Figure 2). Detailed numbering and stratigraphical and lithological information are listed in Table 1. 

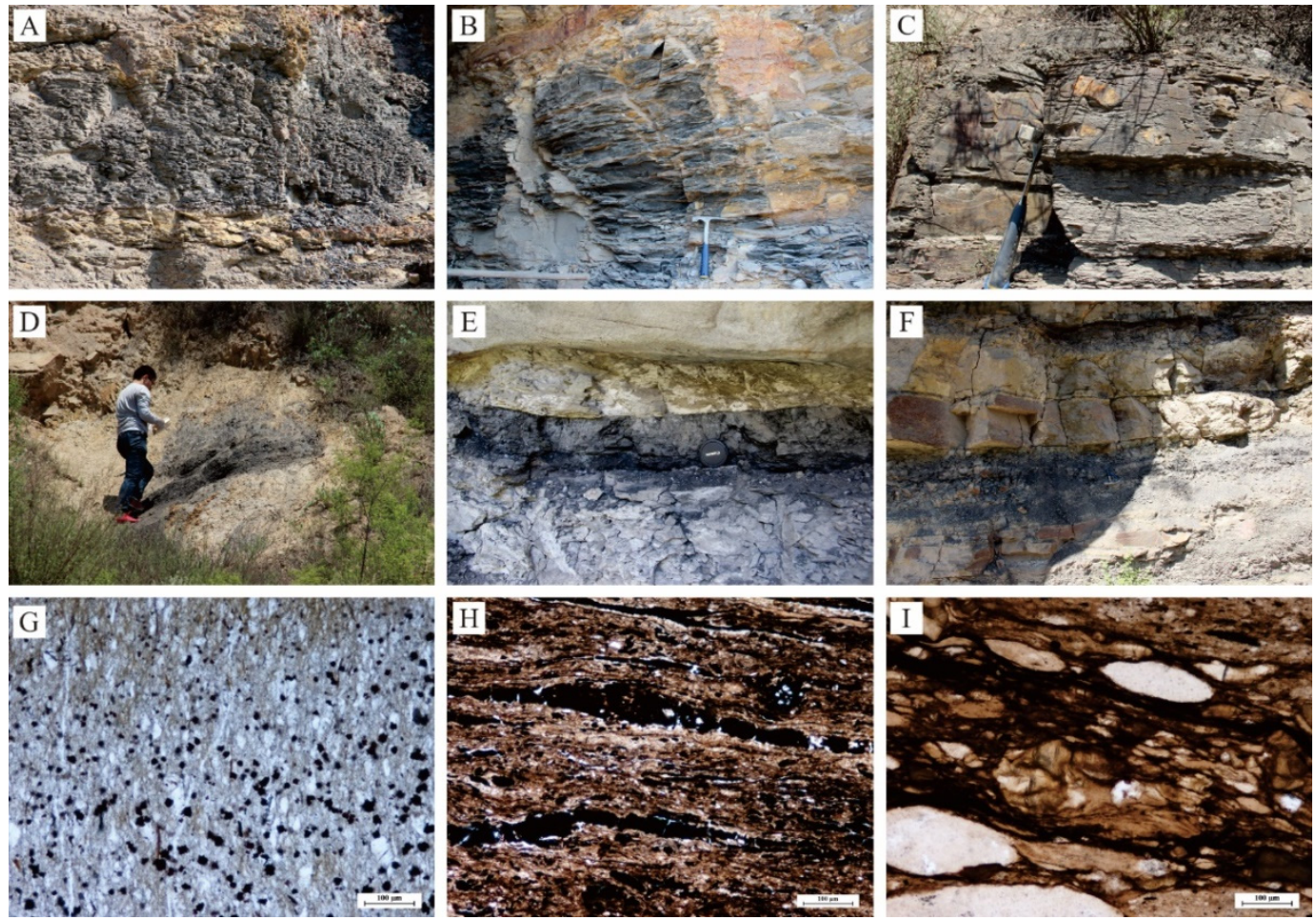

Figure 2. Outcrop photos and micrographs of the studied outcrop: (A) thin black shale at the lower part of the Benxi Formation; (B) thin black shale at the upper part of the Benxi Formation; (C) black shale with calcareous concrete at the Taiyuan Formation; (D) black shales at the 2nd Member of the Shanxi Formation; (E) black shale with coal seams at the 1st Member of the Shanxi Formation; (F) black shale at the top of 1st Member of the Shanxi Formation; (G) micrographs of shale at the Benxi Formation, organic matter grains are shown in black; $(\mathbf{H})$ micrographs of shale at the 1st Member of the Shanxi Formation, organic matter distribute parallel with clay minerals; (I) micrographs of shale at the 1st Member of the Shanxi Formation, showing lenticular clay minerals encased within layer-like organic matter.

\subsection{Sedimentological Characterization}

The studied samples were collected after detailed sedimentological description, and the shale and limestone samples were determined according to their color, grain size, fabric texture and lithofacies were prepared for thin sections production. Then, thin sections were prepared for petrographic analysis by using Zeiss Axio Scope.A1, following the standard SY/T 5368-2016 (identification for thin section of rocks-China National Energy Administration).

\subsection{Organic Matter Contents Analysis}

Total organic carbon (TOC) contents were measured using a CS-230 carbon and sulfur analyzer (LECO) in the Geology Department, Northwest University, China. Each sample was dissolved with hydrochloric acid to remove inorganic carbon and then submitted into burning in the high-temperature oxygen flow. Organic carbon was transformed into carbon dioxide and was measured by infrared detector. Then, the TOC content was able to be calculated.

\subsection{Geochemical Analysis}

Major element analyses were conducted in the State Key Laboratory of Continental Dynamics, Northwest University. The major elements in the sample were analyzed by $X$-ray fluorescence spectroscopy using molten glass made from sample powder and flux $\left(\mathrm{Li}_{2} \mathrm{~B}_{4} \mathrm{O}^{7}\right)$ in a ratio of 1:5 on the RIX2100 system. The internal standard method was applied, with precision of more than $5 \%$. 
Table 1. TOC and major element compositions of Benxi-Shanxi Formations in the Liulin section.

\begin{tabular}{|c|c|c|c|c|c|c|c|c|c|c|c|c|c|c|c|}
\hline No. & Lithology & Strata & TOC & $\mathrm{SiO}_{2}$ & $\mathrm{TiO}_{2}$ & $\mathrm{Al}_{2} \mathrm{O}_{3}$ & $\mathrm{TFe}_{2} \mathrm{O}_{3}$ & $\mathrm{MnO}$ & $\mathrm{MgO}$ & $\mathrm{CaO}$ & $\mathrm{Na}_{2} \mathrm{O}$ & $\mathrm{K}_{2} \mathrm{O}$ & $\mathrm{P}_{2} \mathrm{O}_{5}$ & $\mathrm{~K}_{2} \mathrm{O} / \mathrm{Na}_{2} \mathrm{O}$ & CIA \\
\hline CJZ-7-2 & $\begin{array}{c}\text { Carbonaceous } \\
\text { shale }\end{array}$ & 1st Member, Shanxi Fm. & 20.6 & 53.76 & 0.73 & 22.40 & 1.49 & $<0.01$ & 0.57 & 0.30 & 0.29 & 2.03 & 0.06 & 7.00 & 87.93 \\
\hline CJZ-6-2 & Black shale & 1st Member, Shanxi Fm. & 0.83 & 60.67 & 1.06 & 23.37 & 2.74 & 0.01 & 1.02 & 0.18 & 0.16 & 3.38 & 0.05 & 5.00 & 97.98 \\
\hline CJZ-6-1 & Black shale & 1st Member, Shanxi Fm. & 6.55 & 45.44 & 1.33 & 33.72 & 1.94 & $<0.01$ & 0.36 & 0.27 & 0.08 & 0.40 & 0.06 & 21.13 & 84.98 \\
\hline CJZ-5-3 & Black shale & 1st Member, Shanxi Fm. & 1.54 & 63.55 & 0.89 & 18.94 & 4.29 & 0.01 & 1.40 & 0.15 & 0.60 & 3.24 & 0.09 & 5.40 & 80.63 \\
\hline CJZ-5-2 & Black shale & 1st Member, Shanxi Fm. & 1.8 & 60.36 & 0.74 & 17.69 & 8.25 & 0.11 & 1.57 & 0.24 & 0.56 & 3.30 & 0.11 & 5.89 & 79.13 \\
\hline CJZ-5-1 & Black shale & 1st Member, Shanxi Fm. & & 66.59 & 0.69 & 18.52 & 3.21 & 0.01 & 1.14 & 0.42 & 0.66 & 3.61 & 0.12 & 5.47 & 77.20 \\
\hline CJZ-4-3 & Black shale & 2nd Member, Shanxi Fm. & 1.21 & 60.32 & 0.82 & 22.98 & 2.30 & $<0.01$ & 0.85 & 0.21 & 0.41 & 3.89 & 0.14 & 9.49 & 82.33 \\
\hline CJZ-4-2 & $\begin{array}{c}\text { Carbonaceous } \\
\text { shale }\end{array}$ & 2nd Member, Shanxi Fm. & 35.4 & 22.39 & 0.47 & 11.89 & 14.97 & $<0.01$ & 0.89 & 1.40 & 0.58 & 1.08 & 0.11 & 1.86 & 79.44 \\
\hline CJZ-4-1 & $\begin{array}{c}\text { Carbonaceous } \\
\text { shale }\end{array}$ & 2nd Member, Shanxi Fm. & 12.5 & 42.91 & 0.66 & 23.63 & 1.58 & $<0.01$ & 0.95 & 0.95 & 0.44 & 2.62 & 0.04 & 5.95 & 84.65 \\
\hline CJZ-3-5 & Silty shale & Taiyuan Fm. & 0.59 & 58.45 & 0.43 & 10.96 & 4.79 & 0.16 & 1.73 & 8.61 & 0.21 & 1.56 & 0.22 & 7.43 & 82.16 \\
\hline CJZ-3-4 & Silty shale & Taiyuan Fm. & & 69.41 & 0.40 & 9.60 & 3.42 & 0.18 & 0.84 & 5.55 & 0.19 & 1.52 & 0.09 & 8.00 & 80.87 \\
\hline CJZ-3-2 & Silty shale & Taiyuan Fm. & & 58.34 & 0.44 & 11.07 & 4.11 & 0.15 & 1.61 & 9.59 & 0.21 & 1.58 & 0.09 & 7.52 & 82.18 \\
\hline CJZ-2-6 & Black shale & Benxi Fm. & 2.5 & 53.04 & 1.10 & 25.72 & 3.70 & 0.02 & 0.78 & 0.26 & 0.49 & 2.09 & 0.13 & 4.27 & 88.84 \\
\hline CJZ-2-3 & Black shale & Benxi Fm. & 2.8 & 63.76 & 1.31 & 20.20 & 4.10 & 0.18 & 0.56 & 0.19 & 0.14 & 1.93 & 0.09 & 13.79 & 89.19 \\
\hline CJZ-1-1 & Black shale & Benxi Fm. & 1.51 & 44.52 & 1.24 & 36.07 & 2.17 & 0.00 & 0.55 & 0.15 & 0.17 & 1.90 & 0.11 & 11.18 & 93.89 \\
\hline
\end{tabular}


The chemical index of alteration (CIA) was used to determine the paleoclimate conditions. CIA was calculated using the following formula [27-29]:

$$
\mathrm{CIA}=100 \times \mathrm{Al}_{2} \mathrm{O}_{3} /\left(\mathrm{Al}_{2} \mathrm{O}_{3}+\mathrm{Na}_{2} \mathrm{O}+\mathrm{K}_{2} \mathrm{O}\right)
$$

Trace elements and rare earth elements were measured by inductively coupled plasma mass spectrometry (Agilent 7500A plasma mass Spectrometer, USA) in state Key Laboratory of Continental Dynamics, Northwest University. Firstly, $1.0 \mathrm{~g}$ sample powder was weighed into a porcelain crucible and burned continuously for $2 \mathrm{~h}$ in a Muffle furnace at $800{ }^{\circ} \mathrm{C}$. After cooling the crucible, the sample was weighed again. Then, $50.00 \mathrm{mg}$ sample powder was added to the Teflon microwave digestion vessel. Then, $1.5 \mathrm{~mL}$ nitric acid, $1.5 \mathrm{~mL}$ hydrogen fluoride, and $0.01 \mathrm{~mL}$ hydrochloric acid were added. The mixture was heated to $140{ }^{\circ} \mathrm{C}$ on an electric heating plate until it became a wet salt; then, $1.5 \mathrm{~mL}$ nitric acid and $1.5 \mathrm{~mL}$ hydrogen fluoride were added. The mixture was sealed with steel casing and heated continuously for $48 \mathrm{~h}$ in an oven at $190{ }^{\circ} \mathrm{C}$. After cooling, the mixture was again steamed into wet salt on an electric plate. Then, $3.0 \mathrm{~mL}$ of $50 \%$ nitric acid was added. The mixture was then resealed with a steel sleeve and heated continuously for $12 \mathrm{~h}$ in an oven at $150{ }^{\circ} \mathrm{C}$. After cooling, transfer the resulting solution to a clean PET beaker. At last, the internal standard solution, $\mathrm{Rh}$, and deionized water were added to make the $\mathrm{Rh}$ concentration in the solution $10 \mathrm{ng} / \mathrm{mL}$.

Analyses were performed via three steps. First, $\sim 1.0 \mathrm{~g}$ sample powder was leached with $10 \%$ nitric acid to remove carbonate, phosphate, and sulfide. Each sample was then dried and weighed at $60^{\circ} \mathrm{C}$ and then burned at $550{ }^{\circ} \mathrm{C}$. The ash samples were then leached with $10 \%$ nitric acid to extract the rare earth elements. The solution was processed and measured according to the above procedure, and the residue was dried and weighed again. The analytical precision was greater than $5 \%$.

\subsection{Mineralogical Analysis}

X-ray diffraction (XRD) was analyzed in state Key Laboratory of Continental Dynamics. Preparation, analysis, and interpretation procedures were conducted following the Chinese Oil and Gas Industry Standard (SY/T) 5163-2018. After putting the sample in the groove of the slide, the slides were analyzed by powder X-ray diffraction using a ZJ207 Bruker D8 advance automated powder diffractometer. Slides were scanned from $5^{\circ}$ to $45^{\circ}$ at $2^{\circ} 2 \theta /$ minute and $0.02^{\circ}$ steps using $\mathrm{CuK} \alpha$ radiation and a graphite monochromator.

\section{Results}

\subsection{TOC Content Characteristics}

For the 15 samples in the studied area, TOC contents range from $0.59-35.4 \%$, with an average value of $7.32 \%$. Benxi Formation samples have an average TOC value of $2.27 \%$, Taiyuan Formation samples have an average TOC value of $0.59 \%$, while Shanxi Formation samples have an average TOC value of $10.05 \%$. It should be noted that some samples are carbonaceous shales which have particular TOC values higher than 20\% (Table 1, Figure 3).

\subsection{Mineralogy}

The mineral compositional results from sections and the X-ray diffraction (XRD) data show that samples are mainly composed of clay, quartz, plagioclase, and siderite. Meanwhile, halite, hematite, and goethite only occur in CJZ-2-6, CJZ-4-1, and CJZ-4-2.

In shale, clay and quartz are the dominant minerals in the samples (Table 2). Clay contents average $76.69 \%$ from $55.6-95.1 \%$. Quartz contents range from $4.9-39.7 \%$ with an average of $21.66 \%$. In addition, the contents of plagioclase and siderite vary from $0.8-4.5 \%$ and $0.2-0.7 \%$. 


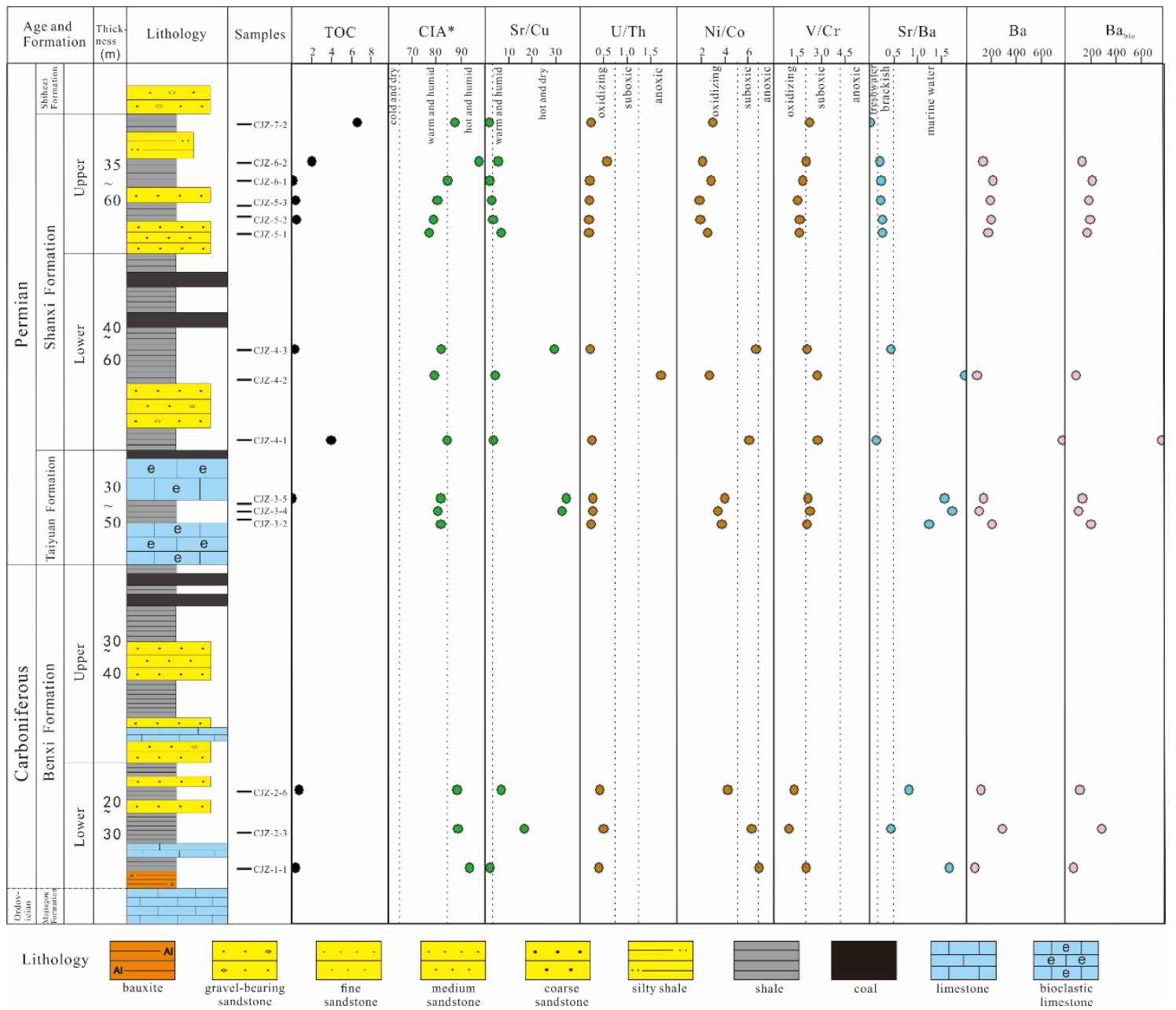

Figure 3. Carboniferous-Permian stratigraphic column for the Liulin section.

Table 2. Mineral compositions of the shales (XRD).

\begin{tabular}{|c|c|c|c|c|c|c|c|c|}
\hline Sample & Clay & Quartz & k-Feldspar & Plagioclase & Halite & Siderite & Hematite & Goethite \\
\hline CJZ-1-1 & 95.1 & 4.9 & 1 & 1 & 1 & 1 & 1 & 1 \\
\hline CJZ-2-6 & 72.3 & 25.6 & 0.5 & 0.8 & 0.1 & 0.7 & & 1 \\
\hline CJZ-4-1 & 80.3 & 18.7 & 1 & 1 & 1 & 0.5 & 0.5 & 1 \\
\hline CJZ-4-2 & 80.7 & 16.7 & 1 & 1 & 1 & 1 & 1 & 2.6 \\
\hline CIZ-4-3 & 67.9 & 30.4 & 1 & 1.2 & 1 & 0.5 & 1 & 1 \\
\hline CJZ-5-3 & 55.6 & 39.7 & 1 & 4.5 & 1 & 0.2 & 1 & 1 \\
\hline CJZ-6-1 & 89.2 & 10.8 & 1 & 1 & 1 & 1 & 1 & 1 \\
\hline CJZ-6-2 & 72.4 & 26.5 & 1 & 0.9 & 1 & 0.2 & 1 & 1 \\
\hline
\end{tabular}

\subsection{Geochemistry}

For the major elements, $\mathrm{SiO}_{2}$ concentration is the highest, with content of $22.39-69.41 \%$, with an average value of $54.9 \%$. The second highest major element is $\mathrm{Al}_{2} \mathrm{O}_{3}$, with content of 9.6-36.07\%, with an average value $20.45 \%$, then followed by, from large to small, $\mathrm{TFe}_{2} \mathrm{O}_{3}$, $\mathrm{K}_{2} \mathrm{O}, \mathrm{CaO}, \mathrm{TiO}_{2}, \mathrm{MgO}$, with content of $1.49-14.97 \%$ (average $4.2 \%$ ), $0.4-3.89 \%$ (average $2.28 \%$ ), $0.4-1.33 \%$ (average 1.9\%), 0.36-1.73\% (average 1.33\%), 0.15-9.59\% (average $0.99 \%$ ). Other major element-oxide contents are lower than $1 \%$ (Table 1). Overall, the major element-oxide content of the Liulin section is similar to the Average Post-Archaean Australian Shale (PAAS) (Ref.), slightly lower than the upper continental crust (UCC) of North of China (UCC of NOC). Al concentration and Si concentration are negatively correlated, with $R^{2}=-0.53$, suggesting the $\mathrm{Si}$ element is mainly in the form of quartz rather than aluminosilicate. Thus, the source of quartz could be inferred as continental flux. 
$\mathrm{CaO}$ content for the samples in the Taiyuan Formation are abnormally higher than others, suggesting that they could be associated with marine environment.

The rare earth element concentration ( $\sum R E E$ ) is 97.00-615.78 ppm, with an average value of $311.63 \mathrm{ppm}$ (Table 3), which is higher than the UCC of NOC (157.07 ppm), the PAAS (183.00 ppm), and the North America shales (173.21 ppm) (Figure 4). Light rare earth element concentration ( $\sum$ LREE) has an average value of $282.04 \mathrm{ppm}$, while heavy rare earth element concentration ( $\sum$ HREE) has an average value of $29.59 \mathrm{ppm}$. Such values are clearly higher than the PAAS; the later has average values of $\sum$ LREE $165.6 \mathrm{ppm}$ and $\sum H R E E=17.4 \mathrm{ppm}$, which is also higher than NCC of NOC (LREE $=144.1 \mathrm{ppm}$; HREE $=12.97 \mathrm{ppm})$. The ratio of light to heavy rare earth element LREE/HREE is 7.29-12.82, with an average value of 9.94. The ratio of $(\mathrm{La} / \mathrm{Yb})_{\mathrm{N}}$ is $8.3-17.32$, with an average value of 12.21. The ratio of $(\mathrm{Gd} / \mathrm{Yb})_{\mathrm{N}}$ is 1.23-2.64, with an average value of 1.88 . $\delta \mathrm{Eu}$ is $0.53-0.69$, with an average value of 0.6 , as a moderate negative anomaly. $\delta \mathrm{Ce}$ is $0.96-1.4$, with an average value of 1.04 , as a weak positive anomaly [30,31].

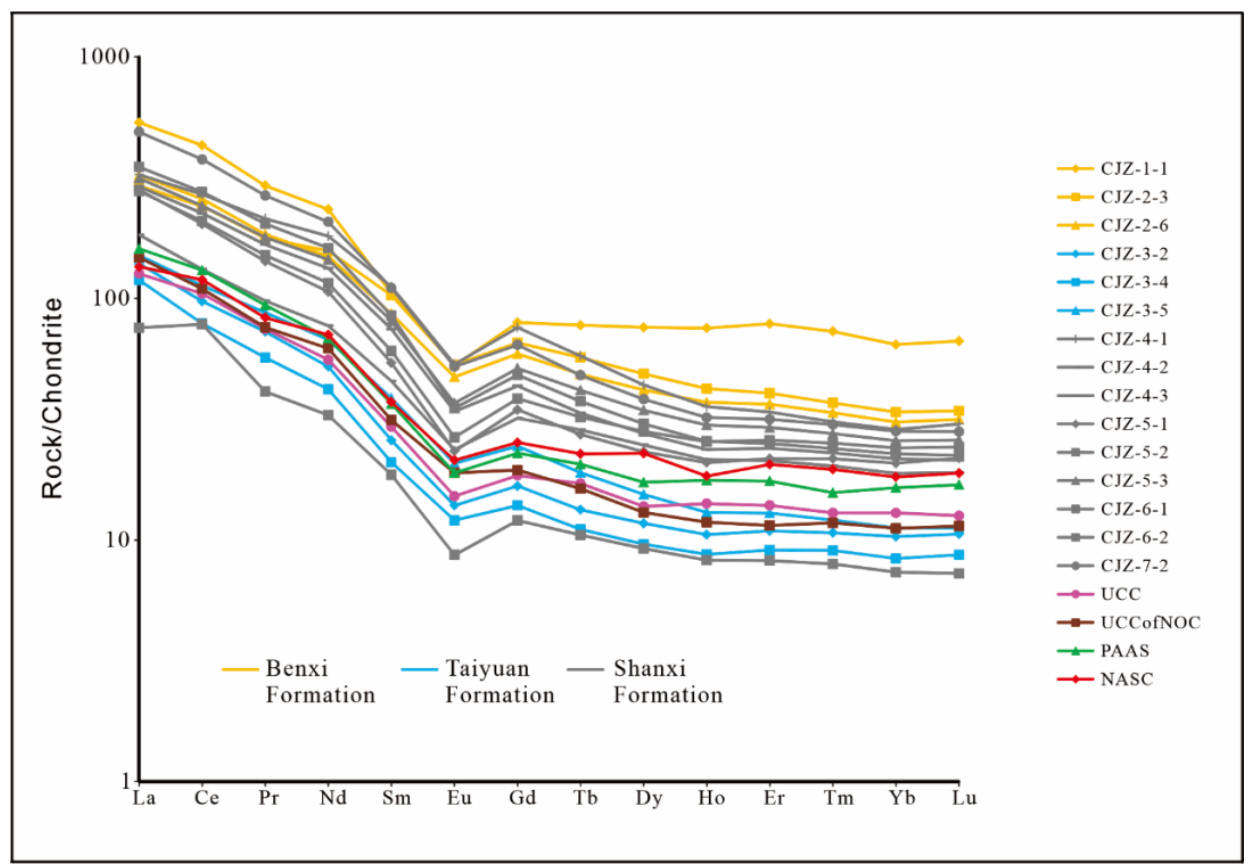

Figure 4. Rare earth element distribution for the Benxi-Shanxi formations at the Liulin section. 
Table 3. Rare earth element compositions of Benxi-Shanxi Formations in the Liulin section.

\begin{tabular}{|c|c|c|c|c|c|c|c|c|c|c|c|c|c|c|c|c|c|c|c|}
\hline No. & La & $\mathrm{Ce}$ & Pr & $\mathrm{Nd}$ & Sm & Eu & Gd & $\mathrm{Tb}$ & Dy & Ho & Er & $\mathrm{Tm}$ & $\mathrm{Yb}$ & Lu & $\delta \mathbf{C e}_{\mathrm{N}}$ & $(\mathrm{La} / \mathrm{Yb})_{\mathrm{N}}$ & $(\mathrm{La} / \mathrm{Sm})_{\mathrm{N}}$ & $(\mathrm{Gd} / \mathrm{Yb})_{\mathrm{N}}$ & $\delta \mathrm{Eu}$ \\
\hline CJZ-7-2 & 115.66 & 229.93 & 25.30 & 96.73 & 16.90 & 3.03 & 13.19 & 1.80 & 9.72 & 1.82 & 5.23 & 0.77 & 4.79 & 0.71 & 1.04 & 17.32 & 4.42 & 2.28 & 0.60 \\
\hline CJZ-6-2 & 82.91 & 168.51 & 19.34 & 75.41 & 12.97 & 2.04 & 9.90 & 1.40 & 7.69 & 1.45 & 4.15 & 0.61 & 3.87 & 0.57 & 1.03 & 15.38 & 4.13 & 2.12 & 0.53 \\
\hline CJZ-6-1 & 17.90 & 47.82 & 3.91 & 15.35 & 2.84 & 0.50 & 2.48 & 0.39 & 2.34 & 0.47 & 1.36 & 0.20 & 1.25 & 0.18 & 1.40 & 10.26 & 4.06 & 1.64 & 0.57 \\
\hline CJZ-5-3 & 74.42 & 147.65 & 16.98 & 67.57 & 12.32 & 2.14 & 10.55 & 1.56 & 8.74 & 1.69 & 4.83 & 0.70 & 4.38 & 0.66 & 1.02 & 12.19 & 3.90 & 1.99 & 0.56 \\
\hline CJZ-5-2 & 65.79 & 127.64 & 14.34 & 54.01 & 9.26 & 1.54 & 7.90 & 1.21 & 7.15 & 1.44 & 4.29 & 0.64 & 4.09 & 0.62 & 1.02 & 11.54 & 4.59 & 1.60 & 0.54 \\
\hline CJZ-5-1 & 66.64 & 124.33 & 13.53 & 49.71 & 8.27 & 1.35 & 7.11 & 1.02 & 5.89 & 1.18 & 3.59 & 0.55 & 3.54 & 0.55 & 1.02 & 13.52 & 5.20 & 1.66 & 0.53 \\
\hline CJZ-4-3 & 68.81 & 137.62 & 15.87 & 62.16 & 11.41 & 1.97 & 8.92 & 1.25 & 7.00 & 1.34 & 3.96 & 0.59 & 3.68 & 0.54 & 1.02 & 13.40 & 3.89 & 2.00 & 0.58 \\
\hline CJZ-4-2 & 43.39 & 80.75 & 9.28 & 35.98 & 6.94 & 1.37 & 6.57 & 1.07 & 6.28 & 1.22 & 3.52 & 0.52 & 3.21 & 0.48 & 0.99 & 9.70 & 4.04 & 1.69 & 0.61 \\
\hline CJZ-4-1 & 77.07 & 164.83 & 20.31 & 84.51 & 17.09 & 3.10 & 15.56 & 2.16 & 11.13 & 2.02 & 5.60 & 0.79 & 4.87 & 0.77 & 1.02 & 11.34 & 2.91 & 2.64 & 0.57 \\
\hline CJZ-3-5 & 35.78 & 69.03 & 8.29 & 31.51 & 5.90 & 1.20 & 5.03 & 0.71 & 3.92 & 0.74 & 2.14 & 0.31 & 1.91 & 0.28 & 0.98 & 13.44 & 3.91 & 2.18 & 0.66 \\
\hline CJZ-3-4 & 28.21 & 48.09 & 5.40 & 19.63 & 3.21 & 0.70 & 2.86 & 0.41 & 2.44 & 0.49 & 1.50 & 0.23 & 1.43 & 0.22 & 0.96 & 14.20 & 5.68 & 1.66 & 0.69 \\
\hline CJZ-3-2 & 32.95 & 59.48 & 6.92 & 24.37 & 3.95 & 0.81 & 3.44 & 0.50 & 2.98 & 0.60 & 1.80 & 0.27 & 1.76 & 0.27 & 0.97 & 13.45 & 5.38 & 1.62 & 0.65 \\
\hline CJZ-2-6 & 76.51 & 157.70 & 17.47 & 69.73 & 13.20 & 2.74 & 12.10 & 1.81 & 10.62 & 2.10 & 6.04 & 0.86 & 5.22 & 0.80 & 1.06 & 10.50 & 3.74 & 1.92 & 0.65 \\
\hline CJZ-2-3 & 69.27 & 146.99 & 16.83 & 73.39 & 15.74 & 3.08 & 13.45 & 2.13 & 12.37 & 2.39 & 6.70 & 0.94 & 5.75 & 0.87 & 1.06 & 8.64 & 2.84 & 1.93 & 0.63 \\
\hline CJZ-1-1 & 126.56 & 263.09 & 27.80 & 109.02 & 16.03 & 3.05 & 16.32 & 2.90 & 19.26 & 4.26 & 13.00 & 1.86 & 10.94 & 1.69 & 1.09 & 8.30 & 5.10 & 1.23 & 0.57 \\
\hline $\begin{array}{c}\text { UCC of } \\
\text { NOC }\end{array}$ & 35.00 & 67.00 & 7.20 & 29.00 & 4.80 & 1.10 & 4.00 & 0.61 & 3.30 & 0.67 & 1.90 & 0.30 & 1.90 & 0.29 & / & / & I & / & / \\
\hline UCC & 30.00 & 64.00 & 7.10 & 26.00 & 4.50 & 0.88 & 3.80 & 0.64 & 3.50 & 0.80 & 2.30 & 0.33 & 2.20 & 0.32 & / & / & / & / & / \\
\hline PAAS & 38.00 & 80.00 & 8.90 & 32.00 & 5.60 & 1.10 & 4.70 & 0.77 & 4.40 & 1.00 & 2.90 & 0.40 & 2.80 & 0.43 & / & / & / & / & / \\
\hline NASC & 32.00 & 73.00 & 7.90 & 33.00 & 5.70 & 1.24 & 5.20 & 0.85 & 5.80 & 1.04 & 3.40 & 0.50 & 3.10 & 0.48 & / & / & / & / & / \\
\hline
\end{tabular}

Note: Subscript $\mathrm{N}$ means ratios after Chondrite standardization; $\delta \mathrm{Ce}=\mathrm{Ce}_{\mathrm{N}} /\left(\mathrm{La}_{\mathrm{N}} \times \mathrm{Pr}_{\mathrm{N}}\right)^{1 / 2} ; \delta \mathrm{Eu}=2 \times \mathrm{Eu} /(\mathrm{Sm}+\mathrm{Gd})$. 


\section{Discussion}

\subsection{Structural Background and Sediment Source}

As the increase of sandstone maturity, feldspars, and other contents in the sandstone can be transformed into potassium-rich clay minerals, the $\mathrm{K}_{2} \mathrm{O} / \mathrm{Na}_{2} \mathrm{O}$ ratio increases accordingly [32]. Therefore, the $\left(\mathrm{K}_{2} \mathrm{O} / \mathrm{Na}_{2} \mathrm{O}\right)-\mathrm{SiO}_{2}$ plot can be used to determine the structural background (Figure 5). The results show that the Benxi Formation lies within the area of active continental margin, the Taiyuan Formation lies within the area of passive continental margin, while the Shanxi Formation lies within the area of active and passive continental margin. The $\Sigma$ REE-La/Yb sediment source plot shows that the Benxi Formation is sourced from alkali basalt, the Taiyuan Formation is mainly sourced from sedimentary rocks, whereas the Shanxi Formation is mainly sourced from felsic granite. The Th/Sc$\mathrm{Zr} / \mathrm{Sc}$ plot shows that the content of the shales in the Taiyuan Formation is mostly similar with the PAAS, whereas the Benxi Formation and the Shanxi Formation are more prone to felsic igneous rocks. Overall, through analyses of major elements, trace elements, and rare earth elements, the Shanxi Formation was sourced from intermediate-acid rocks including felsic igneous rocks and felsic granites, perhaps from the Yinshan Oldland in the northwest direction $[20,33]$.

\subsection{Paleoclimate Conditions}

Source for clastic rocks can be determined according to the geochemical data, yet the precision of this procedure could be influenced by weathering, erosion, transportation, and diagenesis. Nesbitt and Young [24] used the chemical index of alteration (CIA) to quantitatively determine the weathering degree of the source rocks. In Equation (1), the oxides are in a molality unit, and $\mathrm{CaO}^{*}$ represents the density of silicates. The Bock et al. [34] method is applied in the current study: when $\mathrm{CaO} \leq \mathrm{Na}_{2} \mathrm{O}, \mathrm{CaO}=\mathrm{CaO}^{*}$, whereas when $\mathrm{CaO}>\mathrm{Na}_{2} \mathrm{O}, \mathrm{Na}_{2} \mathrm{O}=\mathrm{CaO}^{*}$. CIA has been used to reflect paleoclimate, where a CIA value of 50-65 represents cold and dry climate and weak weathering degree, a CIA value of 65-85 represents warm and humid climate and strong weathering degree, whereas a CIA vale of $85-100$ represents hot and humid climate conditions with strong degree of weathering.

When using CIA to quantitatively determine the weathering degree of the source rock and paleoclimate, sedimentary differentiation, secondary weathering, and potassic metasomatism at the diagenesis should also be considered. Using the A-CN-K plot can determine the weathering of clastic rocks, potassic metasomatism, and composition of clastic rocks $[35,36]$ (Figure 6). Ideally, natural weathering will result in a plot parallel to A-CN or A-K line. Metasomatism will, however, deviate the plot from the original line; the more it deviates from the original line suggests stronger metasomatism. The samples of the studies area mostly fall in a line parallel with A-K, suggesting all the samples were weakly influenced by metasomatism after sedimentation. This also suggests that the geochemical characteristics are weakly influenced by diagenesis, and the CIA could thus be applied to effectively reflect the paleoclimate.

The samples of the studied area have CIA values of 77.2-97.98, with an average value of 84.76 (Table 1), suggesting the source area experienced weak weathering and the paleoclimate was cold and dry. Vertical trends of CIA show that, from Benxi Formation to Taiyuan Formation, the paleoclimate changed from dry and humid to warm and humid, and in the late deposition period of Shanxi Formation, the paleoclimate changed to dry and humid again.

Similarly, trace elopement strontium $(\mathrm{Sr})$ and copper $(\mathrm{Cu})$ are climate-sensitive, and hence, $\mathrm{Sr} / \mathrm{Cu}$ ratios are commonly used to reflect paleoclimate conditions, despite that $\mathrm{Cu}$-bearing syngenetic or detrital sulfide minerals or Sr-bearing barite can influence the concentrations of $\mathrm{Sr}$ and $\mathrm{Cu}$. Sr is easy to lose because of weathering, especially in warm conditions, whereas $\mathrm{Cu}$ can stay relatively stable. Instead, dry and hot conditions lead to 
higher $\mathrm{Sr} / \mathrm{Cu}$ ratios due to the accumulation of $\mathrm{Sr}$ in the parent rock. Many authors use $\mathrm{Sr} / \mathrm{Cu}$ ratios to reflect paleoclimate conditions, assuming $\mathrm{Sr} / \mathrm{Cu}$ ratio of 1-5 to indicate warm and humid conditions and $\mathrm{Sr} / \mathrm{Cu}$ ratio higher than 5 to indicate dry and hot conditions [37]. Whereas $\mathrm{Sr}$ is sometimes related to $\mathrm{Ca}$ in carbonates, $\mathrm{Sr} / \mathrm{Cu}$ ratio is perhaps not a suitable proxy to evaluate the paleoclimate conditions of samples with high Ca content. For this reason, the $\mathrm{Sr} / \mathrm{Cu}$ ratio of Taiyuan Formation is not considered, whereas the Benxi Formation has a $\mathrm{Sr} / \mathrm{Cu}$ ratio of 2.56-16.93, with an average value of 8.92, suggesting dry and hot climate; the Shanxi Formation has a $\mathrm{Sr} / \mathrm{Cu}$ ratio of 2.08-7.24, with an average value of $4.13 \mathrm{~m}$, suggesting warm and humid conditions (Table 4 ).
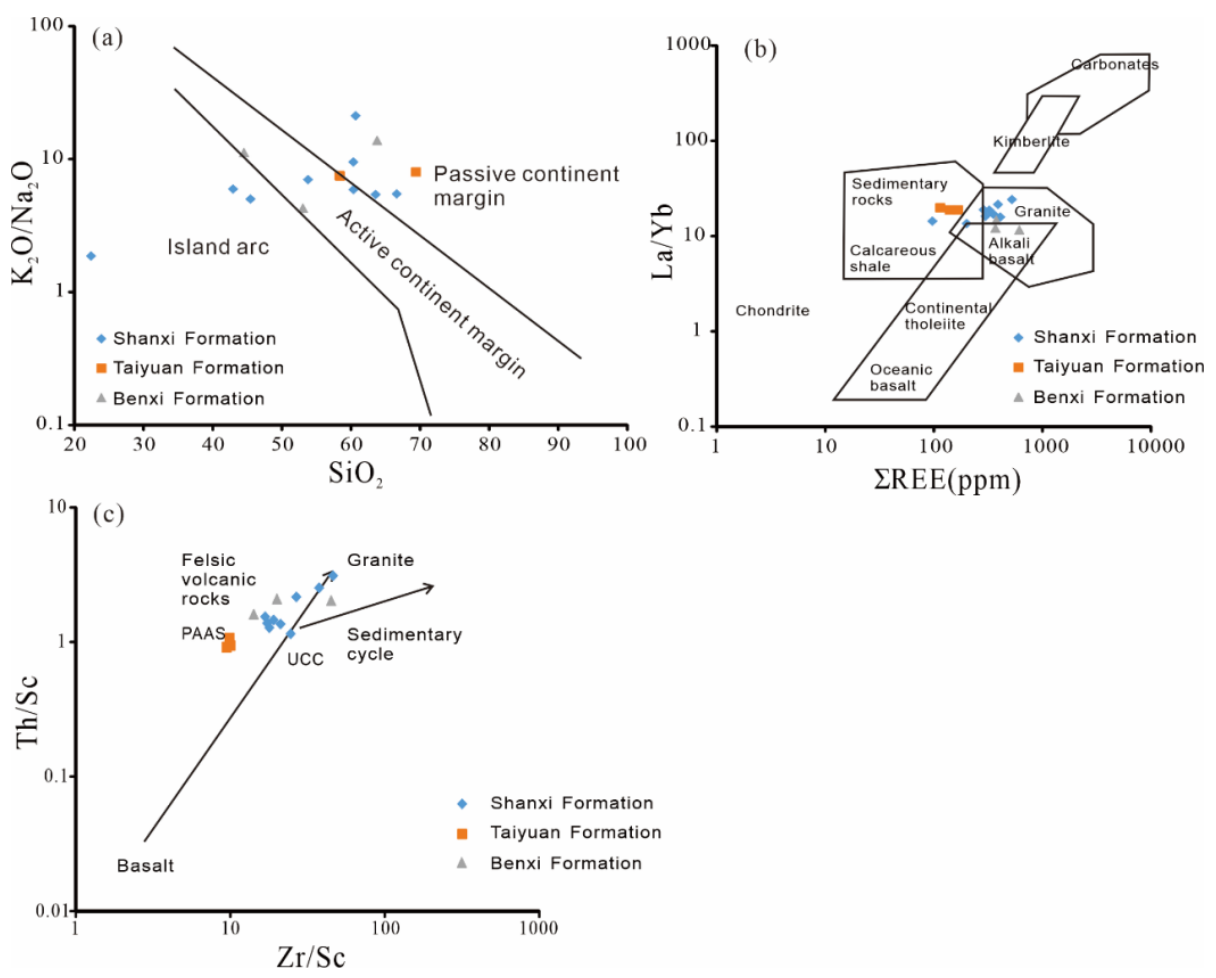

Figure 5. Plot showing structural background and sediment source for the Liulin section. (a) Correlation between $\mathrm{SiO}_{2}$ and $\mathrm{K}_{2} \mathrm{O} / \mathrm{Na}_{2} \mathrm{O}$; (b) Correlation between rare earth element concentration ( $\left.2 R E E\right)$ and $\mathrm{La} / \mathrm{Yb}$; (c) Correlation between $\mathrm{Zr} / \mathrm{Sc}$ and Th/Sc for the Shanxi Formation, Taiyuan Formation, and Benxi Formation.

\subsection{Paleo-Water Salinity}

Sr and Ba are water-salinity-sensitive trace elements. Sr has higher migration capability than $\mathrm{Ba}$, and thus displays different geochemical characteristics in different depositional environments. Sr and Ba exist in low salinity water as soluble bicarbonate, and Ba exists in the form of $\mathrm{BaSO}_{4}$ when water salinity increases. In water with even higher salinity, $\mathrm{Sr}$ only exists in the form of $\mathrm{SrSO}_{4}[38,39]$. The $\mathrm{Sr}$ enrichment in sediments is closely related to increase in water salinity; therefore, high $\mathrm{Sr} / \mathrm{Ba}$ ratios usually suggest an increase in water salinity and water depth [40]. Sr concentrations and $\mathrm{Sr} / \mathrm{Ba}$ ratios are positively correlated to the water salinity, whereas Ba concentrations are negatively correlated to water salinity, and $\mathrm{Sr} / \mathrm{Ba}$ ratio is used as an indicator of water salinity [41].

$\mathrm{Sr}$ and $\mathrm{Ba}$ in sediments can be changed during burial diagenesis. The precision of $\mathrm{Sr} / \mathrm{Ba}$ ratio can be disturbed by the following factors: minerals containing $\mathrm{Sr}$ can release $\mathrm{Sr}$, or $\mathrm{Sr}$ released through authigenic albites or minerals containing $\mathrm{Ca}$, or solution of $\mathrm{Ba}$ in anoxic benthic water. In addition, in carbonate-host rocks, Sr concentrations are high while biogenetic Ba concentrations are low; thus, $\mathrm{Sr} / \mathrm{Ba}$ can increase relative to clay minerals [41]. The $\mathrm{CaO}$ content is generally used as representing carbonate contents, and in most samples, there is a positive correlation between $\mathrm{Sr} / \mathrm{Ba}$ ratio and $\mathrm{CaO}$ when the $\mathrm{CaO}$ content is higher 
than $1.5 \%$. Therefore, $\mathrm{CaO}$ content of $1.5 \%$ is chosen as the maximum threshold for using $\mathrm{Sr} / \mathrm{Ba}$ ratios. In other words, samples with $\mathrm{CaO}$ content higher than $1.5 \%$ are eliminated because they might contain carbonate-hosed Sr. The samples from the Taiyuan limestones are characterized by high Sr concentrations and low Ba concentrations, so Sr/Ba ratio is thus not a precise indicator for the water salinity.

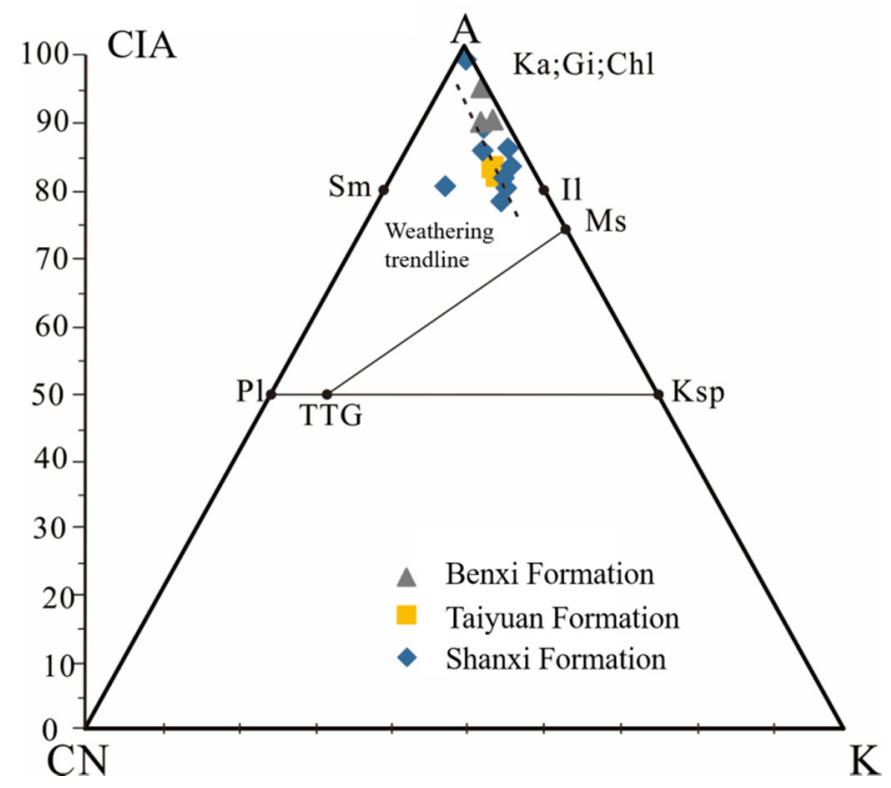

Figure 6. A-CN-K diagram for the Liulin section.

$\mathrm{Sr} /$ Ba ratio of $<0.2,0.2-0.5$, and $>0.5$ represents freshwater, brackish, and marine water, respectively $[19,41]$. The Benxi Formation has Sr/Ba ratio of $0.45-1.66$, with an average value of 0.96 , representing marine water. The Shanxi Formation has Sr/Ba ratio of 0.03-1.98, with an average value of 0.44 (Table 2), mainly suggesting freshwater and brackish water. In the upper Shanxi Formation, the Sr/Ba ratio is low while Al concentration is high, perhaps suggesting sea level drop during that period with less seater influence.

\subsection{Paleoredox Conditions}

Trace elements of Mo, U, V, Co, Ni, Cr, and $\mathrm{Zn}$ are redox-sensitive, and thus, particular ratios such as $\mathrm{U} / \mathrm{Th}, \mathrm{Ni} / \mathrm{Co}$, and $\mathrm{V} / \mathrm{Cr}$ are used as indicators for paleoredox conditions [42-44]. Under anoxic environment, $\mathrm{U}$ can be well conserved in sediments as the form of insoluble $\mathrm{U}^{4+}$ and in the form of soluble $\mathrm{U}^{6+}$ under oxic conditions [43]. In contrast, Th is mostly sourced from clay minerals of clastic materials and exists as soluble $\mathrm{Th}^{4+}$ irrespective of the redox conditions [45]. U/Th values of $>1.25$ and $<0.75$, therefore, represents suboxic/anoxic conditions and oxic marine conditions, respectively.

Trace elements $\mathrm{Co}$ and $\mathrm{Ni}$ generally exist in the form of +2 iron in seawater but have difficulty transforming into sulfide precipitation with highly reducing $\mathrm{H}_{2} \mathrm{~S}$. Co exists in the form of irons or clathrates under oxidizing conditions, yet also in the form of sulfide under anoxic conditions. $\mathrm{Ni}$ exists in the form of $\mathrm{Ni}^{2+}, \mathrm{NiCl}^{+}$, and $\mathrm{NiCO}_{3}$, being soluble in seawater in oxidizing conditions, and it can be easily preserved in sulfides under strongly reducing conditions. In moderate reducing conditions, $\mathrm{Ni}$ in clathrates can be released due to lack of manganite and hydrogen sulfide $[46,47]$. These two trace elements are easily enriched under reducing conditions and are mutually correlated; thus, the $\mathrm{Ni} / \mathrm{Co}$ ratio is commonly used to determine redox conditions. Ni/Co values of $<5,5-7,>7$ represent oxidizing, suboxic, and anoxic environments, respectively. 
Table 4. Trace element compositions of Benxi-Shanxi Formations in the Liulin section.

\begin{tabular}{|c|c|c|c|c|c|c|c|c|c|c|c|c|c|c|c|c|c|c|}
\hline \multirow{2}{*}{ No. } & \multicolumn{11}{|c|}{ Element Concentration/10 ${ }^{-6}$} & \multicolumn{7}{|c|}{ Ratios } \\
\hline & Sc & $\mathbf{V}$ & $\mathrm{Cr}$ & Co & $\mathrm{Ni}$ & $\mathrm{Cu}$ & $\mathrm{Sr}$ & $\mathrm{Zr}$ & Ba & Th & $\mathbf{U}$ & $\mathrm{U} / \mathrm{Th}$ & $\mathrm{V} / \mathrm{Cr}$ & $\mathrm{Ni} / \mathrm{Co}$ & $\mathrm{Sr} / \mathrm{Cu}$ & $\mathrm{Sr} / \mathrm{Ba}$ & $\mathrm{Th} / \mathrm{Sc}$ & $\mathrm{Zr} / \mathrm{Sc}$ \\
\hline CIZ-7-2 & 12.05 & 128.18 & 56.33 & 5.73 & 17.57 & 88.62 & 184.15 & 323.46 & 5987.15 & 25.99 & 6.22 & 0.24 & 2.28 & 3.06 & 2.08 & 0.03 & 2.16 & 26.84 \\
\hline CJZ-6-1 & 5.28 & 43.84 & 20.98 & 8.13 & 17.97 & 10.39 & 61.64 & 244.23 & 266.71 & 16.38 & 9.32 & 0.57 & 2.09 & 2.21 & 5.93 & 0.23 & 3.10 & 46.27 \\
\hline CIZ-5-3 & 15.41 & 90.22 & 58.67 & 16.47 & 31.95 & 27.42 & 89.63 & 326.20 & 374.06 & 20.90 & 4.48 & 0.21 & 1.54 & 1.94 & 3.27 & 0.24 & 1.36 & 21.17 \\
\hline CJZ-5-2 & 14.81 & 83.61 & 50.11 & 13.32 & 26.95 & 29.43 & 109.23 & 265.67 & 387.40 & 18.90 & 3.70 & 0.20 & 1.67 & 2.02 & 3.71 & 0.28 & 1.28 & 17.94 \\
\hline CJZ-5-1 & 10.63 & 57.71 & 35.02 & 5.02 & 13.17 & 13.54 & 98.12 & 399.76 & 344.41 & 26.74 & 5.35 & 0.20 & 1.65 & 2.62 & 7.24 & 0.28 & 2.52 & 37.61 \\
\hline CIZ-4-3 & 13.58 & 148.84 & 69.75 & 1.91 & 12.59 & 20.13 & 594.63 & 228.62 & 1311.06 & 20.88 & 4.72 & 0.23 & 2.13 & 6.60 & 29.53 & 0.45 & 1.54 & 16.84 \\
\hline CIZ-4-2 & 15.32 & 139.58 & 50.13 & 7.99 & 22.10 & 75.17 & 348.11 & 376.93 & 175.66 & 17.57 & 29.67 & 1.69 & 2.78 & 2.77 & 4.63 & 1.98 & 1.15 & 24.60 \\
\hline CJZ-3-5 & 9.96 & 97.62 & 44.55 & 8.75 & 35.45 & 12.31 & 424.44 & 100.01 & 272.60 & 9.36 & 2.59 & 0.28 & 2.19 & 4.05 & 34.49 & 1.56 & 0.94 & 10.04 \\
\hline CIZ-3-4 & 8.61 & 95.98 & 41.28 & 19.52 & 67.68 & 11.08 & 361.56 & 81.64 & 210.59 & 7.83 & 2.20 & 0.28 & 2.32 & 3.47 & 32.63 & 1.72 & 0.91 & 9.49 \\
\hline CJZ-3-2 & 9.39 & 93.68 & 43.68 & 10.69 & 40.44 & 10.94 & 503.35 & 92.95 & 403.79 & 10.02 & 2.42 & 0.24 & 2.14 & 3.78 & 46.01 & 1.25 & 1.07 & 9.90 \\
\hline CJZ-2-6 & 15.44 & 146.97 & 110.85 & 12.84 & 55.03 & 26.78 & 194.35 & 219.45 & 233.88 & 24.75 & 10.50 & 0.42 & 1.33 & 4.28 & 7.26 & 0.83 & 1.60 & 14.22 \\
\hline CIZ-2-3 & 11.00 & 121.94 & 123.00 & 8.61 & 53.77 & 14.80 & 250.52 & 495.73 & 559.30 & 22.32 & 11.26 & 0.50 & 0.99 & 6.25 & 16.93 & 0.45 & 2.03 & 45.05 \\
\hline CIZ-1-1 & 13.49 & 206.09 & 99.48 & 11.16 & 76.45 & 90.15 & 231.24 & 270.85 & 139.67 & 28.10 & 11.14 & 0.40 & 2.07 & 6.85 & 2.56 & 1.66 & 2.08 & 20.08 \\
\hline
\end{tabular}


Trace element $\mathrm{V}$ exists in vanadate in the form of $\mathrm{V}^{4+}$ and can be easily adsorbed into $\mathrm{Fe}^{-}, \mathrm{Mn}^{-}$hydroxide, or kaolinite [48]. Under anoxic environment, especially with abundant sapropel, $\mathrm{V}^{5+}$ is reduced into $\mathrm{V}^{4+}$ and forms $\mathrm{VO}(\mathrm{OH})^{-3}$ and insoluble $\mathrm{VO}(\mathrm{OH})_{2}$. Under anoxic conditions, free $\mathrm{H}_{2} \mathrm{~S}$ will facilitate the transformation of $\mathrm{V}^{4+}$ into $\mathrm{V}^{3+}$, being absorbed by porphyrin or precipitation in the form of $\mathrm{V}_{2} \mathrm{O}_{3}, \mathrm{~V}(\mathrm{OH})_{3}$. In oxygen-rich seawater, $\mathrm{Cr}$ exists in the form of soluble $\mathrm{Cr}^{4+}\left(\mathrm{CrO}_{4}{ }^{2-}\right)$. In suboxic environment, $\mathrm{Cr}^{4+}$ can be transformed to $\mathrm{Cr}^{3+}$, forming $\mathrm{Cr}(\mathrm{OH})^{2+}, \mathrm{Cr}(\mathrm{OH})_{3}$, and $(\mathrm{CrFe})(\mathrm{OH})_{3}$. They are easily absorbed by humic acid or hydroxide of $\mathrm{Fe}$ and $\mathrm{Mn}$ and are thus preserved into sediments. Sedimentary $\mathrm{Cr}$ is not easily captured by FeS during the organic organism mineralization but is easy to diffuse and enter into a water column in a convective mode. $\mathrm{V} / \mathrm{Cr}$ ratio are redox indicators with $<2,2-4.25$, and $>4.25$ representing oxidizing, suboxic, and anoxic environment, respectively.

For U/Th ratios, the value is $0.2-1.69$, with average 0.4 (Table 2), suggesting the Benxi Formation to Shanxi Formation are oxidizing environments. For Ni/Co ratios, the value is 1.94-6.85, with average 3.92 (Table 2), suggesting the Benxi Formation is a suboxic-oxidizing environment, the Taiyuan Formation is an oxidizing environment, the 2nd Member of Shanxi Formation is a suboxic environment, and the 1st Member of Shanxi Formation is a suboxic-oxidizing environment. For $\mathrm{V} / \mathrm{Cr}$ ratios, the value is $0.99-2.79$, with average 1.99 (Table 2), suggesting an oxidizing environment for the Benxi Formation, suboxic environment for the Taiyuan Formation, suboxic environment for the 2nd Member of the Shanxi Formation, and suboxic-oxidizing environment for the 1st Member of the Shanxi Formation.

Due to the limited number of samples, different redox proxies can have different predictions. Overall, these redox proxies indicate more oxidizing conditions for the Benxi and Taiyuan Formation, and a transition from suboxic environment to oxidizing environment from the 2nd Member to the 1st Member of the Shanxi Formation.

\subsection{Paleo-Productivity}

Paleo-productivity represents the capacity of organisms fixing energy during the depositional process, and nutrient element abundance is commonly used to evaluate the paleo-productivity. Many authors study the effects of elements on paleoproductivity by culturing bacteria and observing the growth of marine organisms. Consequently, elements such as $\mathrm{Cu}, \mathrm{Ba}, \mathrm{Fe}, \mathrm{Ni}, \mathrm{N}$, etc., are vital for the growth of organisms. However, inorganic elements have various sources, and only the nutrient elements in organisms can reflect the paleo-productivity. When biogenetic Ba content ranges from 1000 to $5000 \mathrm{ppm}$, a high paleo-productivity environment can be determined [12]. Meanwhile, $\mathrm{Cu}, \mathrm{Fe}$, and Ni may be influenced not only by seawater redox conditions but also by $\mathrm{pH}$ value, yet $\mathrm{Ba}$ and $\mathrm{P}$ concentrations can remain stable irrespective of those environments.

The accumulation rate of phosphorus (PAR) and accumulation rate of barium (BaAR) proposed by Schoepfer. [49] are used in this study to evaluate the paleo-productivity of ancient sea. The concentration of elements is calculated as follows:

$$
\mathrm{A}_{\mathrm{xs}}=\mathrm{A}-\mathrm{Al} \times(\mathrm{A} / \mathrm{Al})_{\text {detr }}
$$

In Equation (2), Axs represents the concentration of biogenetic elements $\left(\mathrm{Ba}_{\mathrm{bio}}\right.$ and $\left.\mathrm{P}_{\text {org }}\right), \mathrm{A}$ and $\mathrm{Al}$ represent $\mathrm{Ba}, \mathrm{P}$, and $\mathrm{Al}$ concentrations in the analyzed samples, and (A/Al)detr represents the ratio of background elements. Many studies use element ratio of UCC or PAAS as the background, but the samples in this study are different from UCC or PAAS, and considering the fact that nutrient elements might be lost during the weathering and transporting processes, this paper use the minimum $\mathrm{A} / \mathrm{Al}$ of the samples as the $(\mathrm{A} / \mathrm{Al}) \operatorname{detr}[26,49,50]$. The accumulation rate of phosphorus (PAR) and accumulation rate of barium (BaAR) are calculated as follows:

$$
\operatorname{MAR}(X)=(X) \times \operatorname{BAR}
$$


In Equation (3), X means TOC, organic phosphorus $\left(\mathrm{P}_{\text {org }}\right)$, and biogenetic barium (Ba bio $\left._{\text {b }}\right)$. MAR shows the mass accumulation rate $\left(\mathrm{g} \cdot \mathrm{cm}^{-2} \cdot \mathrm{kyr}^{-1}\right)$. BAR refers to Schoepfer et al. [47], as shown in Equation (4):

$$
\mathrm{TOC}=10^{-3.09} \times \mathrm{BAR}^{0.72}
$$

The results in the current study have Ba bio concentration of 134.29-5900.41 ppm, with an average of 1105.41 ppm (Table 5), suggesting relatively high paleo-productivity. Among the samples, the Shanxi Formation has higher $\mathrm{Ba}_{\text {bio }}$ concentrations than the Taiyuan Formation and the Benxi Formation and has lower $P_{\text {org }}$ concentrations than the Taiyuan Formation and the Benxi Formation. The PAR and BaAR of the Shanxi Formation are generally higher than the Taiyuan Formation and the Benxi Formation, all suggesting higher paleo-productivity of the Shanxi Formation.

Table 5. The indexes of productivity of Benxi-Shanxi Formations in the Liulin section.

\begin{tabular}{ccccccc}
\hline No. & TOC & Babio & Porg & BAR & PAR & BaAR \\
\hline CJZ-7-2 & 20.60 & 5900.41 & 0.01 & $1,307,622.10$ & $12,705.22$ & $7.72 \times 10^{9}$ \\
CJZ-6-2 & 6.55 & 136.14 & 0.00 & $266,277.91$ & 342.18 & $3.63 \times 10^{7}$ \\
CJZ-6-1 & 0.83 & 326.26 & 0.00 & $15,110.37$ & 69.41 & $4.93 \times 10^{6}$ \\
CJZ-5-3 & 1.54 & 300.72 & 0.03 & $35,654.32$ & 908.95 & $1.07 \times 10^{7}$ \\
CJZ-5-2 & 1.80 & 318.90 & 0.04 & $44,280.43$ & 1559.75 & $1.41 \times 10^{7}$ \\
CJZ-4-3 & 1.21 & 1222.07 & 0.04 & $25,506.23$ & 1134.63 & $3.12 \times 10^{7}$ \\
CJZ-4-1 & 12.50 & 1379.74 & 0.00 & $653,360.38$ & 0.11 & $9.01 \times 10^{8}$ \\
CJZ-3-5 & 0.59 & 230.16 & 0.09 & 9406.01 & 833.72 & $2.16 \times 10^{6}$ \\
CJZ-2-6 & 2.50 & 134.29 & 0.04 & $69,881.32$ & 2658.53 & $9.38 \times 10^{6}$ \\
CJZ-1-1 & 1.51 & 0.00 & 0.02 & $34,693.31$ & 747.11 & 6.11 \\
\hline
\end{tabular}

\subsection{Controlling Factors of Organic Matter Accumulation}

In order to unravel the impact of paleo-climate, paleo-water salinity, paleo-redox, and paleo-productivity on the organic matter accumulations, TOC is used as the indicator for the organic matter accumulation, and the correlation of TOC to the proxies of these controlling factors (e.g., CIA for paleo-climate, $\mathrm{Sr} / \mathrm{Ba}$ for paleo-water salinity, U/Th and V/Cr for paleo-redox, and $\mathrm{Ba}_{\text {bio, }}, \mathrm{P}_{\text {org }}, \mathrm{PAR}, \mathrm{BaAR}$ for paleo-productivity) are investigated. The results shows that TOC is not correlated to the CIA and $\mathrm{Sr} / \mathrm{Ba}$ (Figure $7 \mathrm{~A}, \mathrm{~B}$ ), it is negatively correlated with Porg $\left(\mathrm{R}^{2}=0.41\right.$, Figure $\left.7 \mathrm{~F}\right)$, whereas it is positively correlated with $\mathrm{U} / \mathrm{Th}$ $\left(R^{2}=0.63\right.$, Figure $\left.7 C\right)$ and V/Cr $\left(R^{2}=0.48\right.$, Figure $\left.7 D\right), B_{\text {bio }}\left(R^{2}=0.78\right.$, Figure $\left.7 E\right)$, BaAR $\left(R^{2}=0.78\right.$, Figure $\left.7 G\right)$, and PAR $\left(R^{2}=0.59\right.$, Figure $\left.7 H\right)$. The correlations suggest that the paleo-redox conditions and paleo-productivity are the two most relevant controlling factors controlling the organic-matter abundance in the studied section.

High paleo-productivity provides the material base for the organic matter enrichment. After being formed, organic matter would be buried and preserved and then be accumulated. Environments with deep water depth, reducing conditions, and low hydrodynamic conditions favor the preservation and accumulation of organic matters. Recent studies added that, in the oxidizing-suboxic environment, continuous detrital influx and relatively high sedimentation rate could accelerate the burial of organic matter, hence shorten the time when organic matters are exposed in the oxygen-rich water. Organic matter can be therefore accumulated under such oxidizing environments [19,50-52]. The Benxi Formation was controlled by an epic-continental sea environment while transiting upwards into a transitional environment. The Taiyuan formation is affected by marine environment, and the Shanxi formation was deposited in a transitional environment [19]. The lower Shanxi Formation was tidal flat-lagoonal facies, which is geographically in the transition of marine to continental region, characterized by a high sedimentation rate. A large quantity of detrital influx with abundant terrestrial origin plants as well as a warm and humid environment favors weathering process and can result in a more eutrophic body of water, favoring the growth of lower plants such as phycomycetes. All these factors 
support the organic matter accumulation within the sedimentary rocks and shales of the Shanxi Formation in this study.
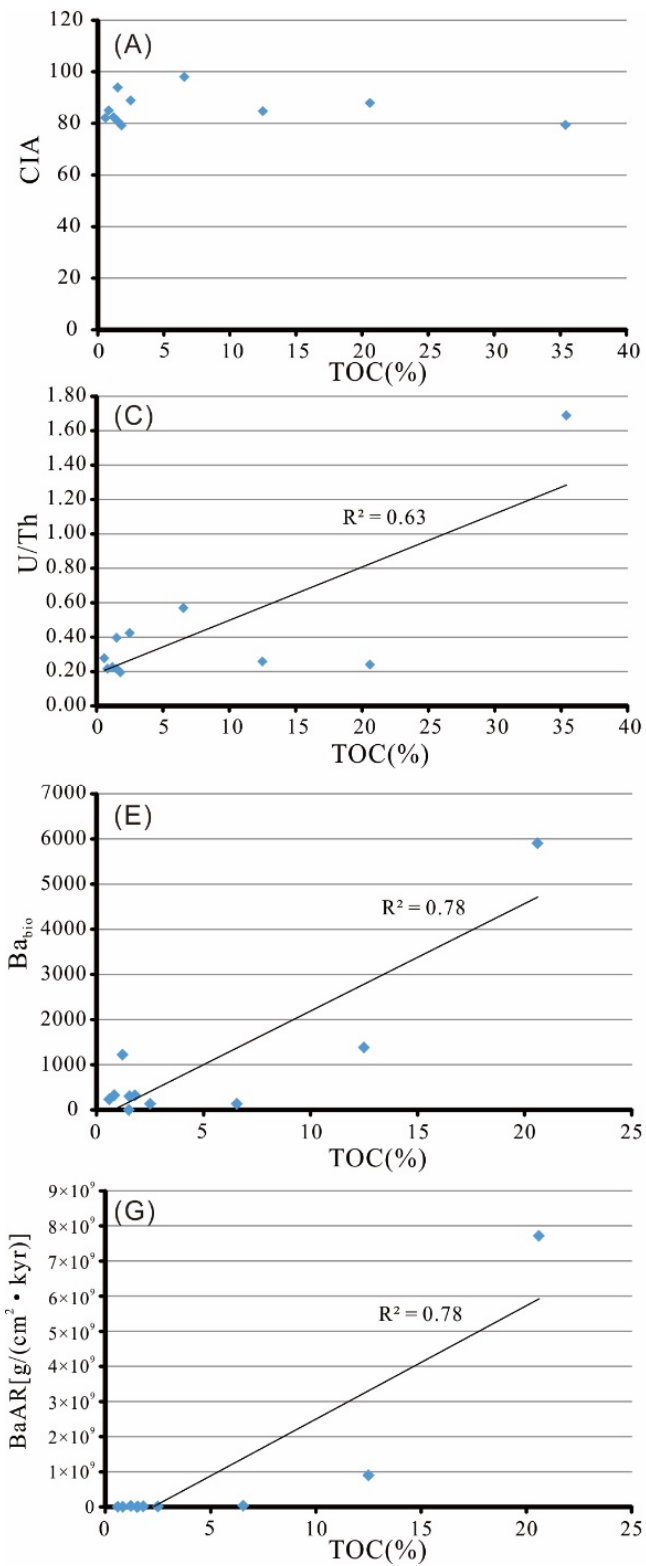
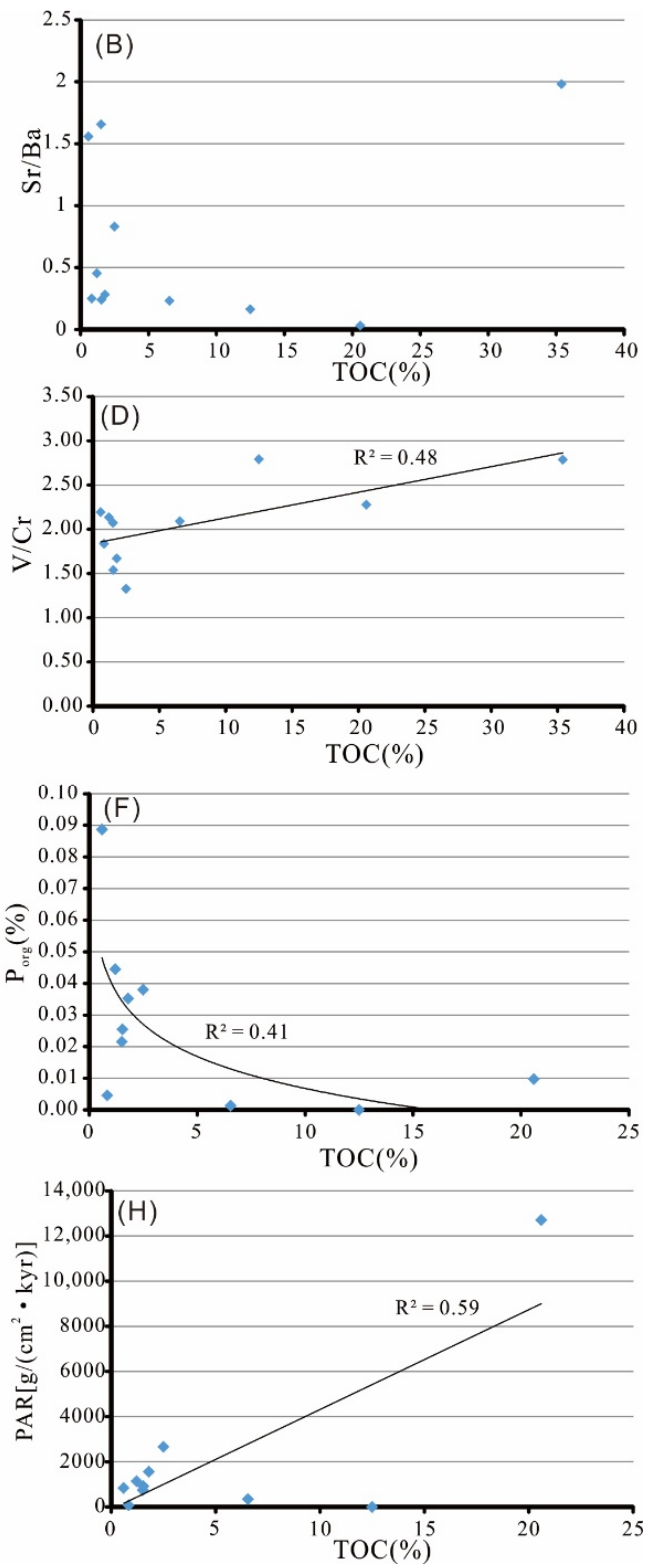

Figure 7. Correlation of TOC with paleoclimate, paleo-water salinity, paleoproductivity, and paleoredox proxies: (A) Correlations between TOC and CIA; (B) Correlations between TOC and $\mathrm{Sr} / \mathrm{Ba}$; (C) Correlations between TOC and U/Th; (D) Correlations between TOC and V/Cr; (E) Correlations between TOC and $\mathrm{Ba}_{\text {bio }} ;(\mathrm{F})$ Correlations between TOC and $\mathrm{P}_{\text {org }} ;(\mathrm{G})$ Correlations between TOC and BaAR; (H) Correlations between TOC and PAR.

\section{Conclusions}

(1) The Benxi Formation is a barrier island-lagoon facies composed of carbonaceous shales interbedding tidal channel sandstones and coals. The Taiyuan Formation is a tidal flat-shelf facies composed of bioclastic limestones interbedding black shales and coals. The Shanxi Formation is a tidal flat-lagoon facies composed of grey sandstones and dark grey-black shales with occasional coals. The Shanxi Formation has the highest TOC contents, ranging from $0.59-35.4 \%$, with an average of $7.32 \%$.

(2) Geochemical proxies suggest that the Shanxi Formation is sourced from intermediateacid rocks, perhaps felsic igneous rocks and granites from the Yinshan Oldland in 
the northwest. From the Benxi to Taiyuan depositional period, the climate changed from hot and humid to warm and humid with continuously increasing humidity. In the late period of the Shanxi Formation, the climate changed to hot and humid again, and the depositional environment was characterized by oxidizing conditions with relatively high paleo-productivity.

(3) Black shales in the Shanxi Formation and Benxi Formation were controlled by the paleoredox conditions and paleoproductivity. Despite the oxic-suboxic conditions, the lower part of the Shanxi Formation was developed in a marine-continental transitional environment, with large quantity of detrital influx, and sedimentation rate was rather fast. A warm and humid climate favored the weathering process, resulting in higher productivity in the water column as well as thriving of inferior aquatic organisms. All these factors provide the material basis for the accumulation of organic matter.

Author Contributions: Conceptualization, L.Z. and Q.Z. (Qun Zhao); methodology, Y.W. and Q.Z. (Qun Zhao); software, S.P.; data curation, L.Z. and C.F.; analysis, S.P. and S.Z.; resources, Q.Z. (Qin Zhang); writing—original draft preparation, L.Z.; writing—review and editing, S.P., Q.Z. (Qun Zhao) and D.D.; project administration, Q.Z. (Qun Zhao) and Z.Q.; funding acquisition, Q.Z. (Qun Zhao). All authors have read and agreed to the published version of the manuscript.

Funding: This research was funded by PETROCHINA, grant number 2021DQ0402.

Institutional Review Board Statement: Not applicable.

Informed Consent Statement: Not applicable.

Data Availability Statement: Not applicable.

Conflicts of Interest: The authors declare no conflict of interest.

\section{References}

1. Zou, C.N.; Dong, D.Z.; Wang, Y.; Li, X.; Huang, J.; Wang, S.; Guan, Q.; Zhang, C.; Wang, H.; Liu, H. Shale gas in China: Characteristics, challenges and prospects(I). Pet. Explor. Dev. 2015, 42, 689-701. [CrossRef]

2. Dong, D.; Zou, C.; Dai, J.; Huang, S.; Zheng, J.; Gong, J.; Wang, Y.; Li, X.; Guan, Q.; Zhang, C. Suggestions on the development strategy of shale gas in China. J. Nat. Gas Geosci. 2016, 27, 397-406. [CrossRef]

3. Kuang, L.; Dong, D.; Wenyuan, H.E.; Wen, S.; Zhang, S. Geological characteristics and development potential of transitional shale gas in the east margin of the Ordos Basin, NW China. Pet. Explor. Dev. 2020, 47, 471-482. [CrossRef]

4. Qiu, Z; Zou, C.N. Unconventional Petroleum Sedimentology: Connotation and prospect. Acta Sedimentol. Sin. 2020, 38, 1-29.

5. Zhang, J.C.; Jiang, S.L.; Tang, X.; Zhang, P.X.; Tang, Y.; Jing, T.Y. Accumulation types and resources characteristics of shale gas in China. Nat. Gas Ind. 2009, 29, 109-114.

6. Zou, C.N.; Dong, D.Z.; Yang, H.; Wang, Y.; Huang, J.; Wang, S.; Fu, C. Conditions of shale gas accumulation and exploration practices in China. Nat. Gas Ind. 2011, 31, 26-39.

7. Dong, D.Z.; Zou, C.N.; Li, J.Z.; Wang, S.J.; Huang, J.L. Resource potential, exploration and development prospect of shale gas in the whole world. Geol. Bull. China 2011, 30, 324-336.

8. Guo, X.; Hu, D.; Liu, R.; Wei, X.; Wei, F. Geological conditions and exploration potential of Permian marine-continent transitional facies shale gas in the Sichuan Basin. Nat. Gas Ind. 2019, 6, 198-204. [CrossRef]

9. Arthur, M.A.; Sageman, B.B. Marine Black Shales: Depositional Mechanisms and Environments of Ancient Deposits. Annu. Rev. Earth Planet. Sci. 1994, 22, 499-551. [CrossRef]

10. Algeo, T.J.; Lyons, T.W. Mo-total organic carbon covariation in modern anoxic marine environments: Implications for analysis of paleoredox and paleohydrographic conditions. Paleoceanography 2006, 21, 16-23. [CrossRef]

11. Jiang, S.Y.; Zhao, H.X.; Chen, Y.Q.; Tao, Y.; Yang, J.H.; Ling, H.F. Trace and rare earth element geochemistry of phosphate nodules from the lower Cambrian black shale sequence in the Mufu Mountain of Nanjing, Jiangsu province, China. Chem. Geol. 2007, 244, 584-604. [CrossRef]

12. Pi, D.H.; Liu, C.Q.; Shields-Zhou, G.A.; Jiang, S.Y. Trace and rare earth element geochemistry of black shale and kerogen in the early Cambrian Niutitang Formation in Guizhou province, South China: Constraints for redox environments and origin of metal enrichments. Precambrian Res. 2013, 225, 218-229. [CrossRef]

13. Sweere, T.; van den Boorn, S.; Dickson, A.J.; Reichart, G.J. Definition of new trace-metal proxies for the controls on organic matter enrichment in marine sediments based on Mn, Co, Mo and Cd concentrations. Chem. Geol. 2016, 441, 235-245. [CrossRef]

14. Zhang, H.F.; Xinsong, W.U.; Wang, B.; Duan, Y.J.; Yang, Q.U.; Chen, D.F. Research Progress of the Enrichment Mechanism of Sedimentary Organics in Lacustrine Basin. Acta Sedimentol. Sin. 2016, 34, 463-477. 
15. Qiu, Z.; Lu, B.; Chen, Z.H.; Zhang, R.; Dong, D.Z.; Wang, H.Y.; Qiu, J.L. Discussion of the Relationship between Volcanic Ash Layers and Organic Enrichment of Black Shale: A case study of the Wufeng-Longmaxi gas shales in the Sichuan Basin. Acta Sedimentol. Sin. 2019, 37, 1296-1308.

16. Lin, F.; Fu, X.G.; Wang, J.; Song, C.Y. Mechanism of organic matter accumulation in a marine-terrestrial transitional residual bay environment: A case of Early Cretaceous organic-rich shales in the Qiangtang Basin, Tibet. Geol. China 2021, 1-20, Accepted Online.

17. He, J.W.; Xie, Y.; Liu, J.Q.; He, L. Mechanism of organic matter enrichment of fine-grained sedimentary rocks in the Southwest margin of Upper Yangtze: A case study of the Niuzhai section, Yanjin. Acta Sedimentol. Sin. 2021, 39, 656-671.

18. Ding, J.H.; Zhang, J.C.; Shi, G.; Shen, B.J.; Tang, X.; Yang, Z.H.; Li, X.Q.; Li, C.X. Sedimentary environment and organic matter enrichment mechanisms of the Upper Permian Dalong Formation shale, southern Anhui Province, China. Oil Gas Geol. 2021, 42, 158-172.

19. Zhang, L.F.; Dong, D.; Qiu, Z.; Wu, C.; Pan, S. Sedimentology and geochemistry of Carboniferous-Permian marine-continental transitional shales in the eastern Ordos Basin, North China. Palaeogeogr. Palaeoclimatol. Palaeoecol. 2021, 571, 110389. [CrossRef]

20. Luo, J.L.; Wei, X.S.; Yao, J.L.; Liu, X.S.; Liu, X.H. Provenance and depositional facies controlling on the Upper Paleozoic excellent natural gas-reservoir in northern Ordos basin, China. Geol. Bull. China 2010, 29, 811-820.

21. Dong, D.Z.; Qiu, Z.; Zhang, L.F.; Li, S.X.; Zhang, Q.; Li, X.T.; Zhang, S.R.; Liu, H.L.; Wang, Y.M. Progress on sedimentology of transitional facies shales and new discoveries of shale gas. Acta Sedimentol. Sin. 2021, 39, $29-45$.

22. Yang, Y.; Li, W.; Ma, L. Tectonic and stratigraphic controls of hydrocarbon systems in the Ordos basin: A multicycle cratonic basin in central China. AAPG Bull. 2005, 89, 255-269. [CrossRef]

23. Zhao, Z.Y.; Guo, Y.R.; Wang, Y.; Lin, D.J. Study progress in tectonic evolution and paleogeography of Ordos Basin. Spec. Oil Gas Reserv. 2012, 19, 15-20.

24. Yang, X.C.; Qu, Z.H.; Jiang, B.; Zhou, K.; Zhang, J.K. Mesozoic-Cenozoic structural features and their evolution in Daning-Jixian area, Shanxi. Coal Geol. China 2013, 25, 1-6.

25. Zhao, K.Y.; Guo, S.B. Characteristics and main controlling factors of shale gas reservoirs in transitional facies: A case study of Upper Paleozoic in Ordos Basin. Pet. Geol. Exp. 2015, 37, 141-149.

26. Qu, H.J.; Han, X.; Chen, S.; Yang, B.; Du, M.Y.; Dong, Y.Y.; Zhao, C. U-Pb Dating of Detrital Zircon from the Upper Paleozoic Clastic Rocks and Basin-mountain Coupling of the Northeastern Ordos Basin. Geotecton. Metallog. 2020, 44, 501-527.

27. Nesbitt, H.W.; Young, G.M. Early Proterozoic climates and plate motions inferred from major element chemistry of lutites. Nature 1982, 299, 715-717. [CrossRef]

28. Velbel, P. Chemical weathering indices applied to weathering profiles developed on heterogeneous felsic metamorphic parent rocks. Chem. Geol. 2003, 202, 397-416.

29. Ma, K.; Hu, S.; Wang, T.; Zhang, B.; Qin, S.; Shi, S.; Wang, K.; Qingyu, H. Sedimentary environments and mechanisms of organic matter enrichment in the Mesoproterozoic Hongshuizhuang Formation of northern China. Palaeogeogr. Palaeoclimatol. Palaeoecol. 2017, 475, 176-187. [CrossRef]

30. Masuda, A. Regularities in variation of relative abundances of lanthanide elements and an attempt to analyse separation index patterns of some minerals. J. Earth Sci. 1962, 10, 173-187.

31. Coryell, C.D.; Chase, J.W.; Winchester, J.W. A procedure for geochemical interpretation of terrestiral rare-earth abundance patterns. Geophys. Res. 1963, 68, 559-566. [CrossRef]

32. Roser, B.P.; Korsch, R.J. Determination of tectonic setting of sandstone-mudstone suites using $\mathrm{SiO}_{2}$ content and $\mathrm{K}_{2} \mathrm{O} / \mathrm{Na}_{2} \mathrm{O}$ ratio. J. Geol. 1986, 94, 635-650. [CrossRef]

33. Qu, H.J.; Ma, Q.; Gao, S.L. On Provenance of the Permian in the Southeastern Ordos Basin. Acta Geol. Sin. 2011, 85, 979-986.

34. Bock, B.; Mclennan, S.M.; Hanson, G.N. Geochemistry and provenance of the Middle Ordovician Austin Glen Member (Normanskill Formation) and the Taconian Orogeny in New England. Sedimentology 2010, 45, 635-655. [CrossRef]

35. Fedo, C.M.; Wayne Nesbitt, H.; Young, G.M. Unraveling the effects of potassium metasomatism in sedimentary rocks and paleosols, with implications for paleoweathering conditions and provenance. Geology 1995, 23, 921. [CrossRef]

36. Sensarma, S.; Rajamani, V.; Tripathi, J.K. Petrography and geochemical characteristics of the sediments of the small River Hemavati, Southern India: Implications for provenance and weathering processes. Sediment. Geol. 2008, 205, 111-125. [CrossRef]

37. Yandoka, B.S.; Abdullah, W.H.; Abubakar, M.B.; Hakimi, M.H.; Adegoke, A.K. Geochemical characterisation of Early Cretaceous lacustrine sediments of Bima Formation, Yola Sub-basin, Northern Benue Trough, NE Nigeria: Organic matter input, preservation, paleoenvironment and palaeoclimatic conditions. Mar. Pet. Geol. 2015, 61, 82-94. [CrossRef]

38. Wang, Y.Y.; Guo, W.Y.; Zhang, G.D. Application of Some Geochemical Indicators in Determining of Sedimentary Environment of the Funing Group (Paleogene), Jin-Hu Depression, Kiangsu Province. J. Tongji Univ. 1979, 7, 51-60.

39. Wolgemuth, K.; Broecker, W.S. Barium in sea water. Earth Planet. Sci. Lett. 1970, 8, 372-378. [CrossRef]

40. Chegrouche, S.; Mellah, A.; Barkat, M. Removal of strontium from aqueous solutions by adsorption onto activated carbon: Kinetic and thermodynamic studies. Desalination 2009, 235, 306-318. [CrossRef]

41. Wei, W.; Algeo, T.J. Elemental proxies for paleosalinity analysis of ancient shales and mudrocks. Geochim. Et Cosmochim. Acta 2019, 287, 341-366. [CrossRef]

42. Algeo, T.J.; Tribovillard, N. Environmental Analysis of Paleoceanographic Systems Based on Molybdenum-Uranium Covariation. Chem. Geol. 2009, 268, 211-225. [CrossRef] 
43. Tribovillard, N.; Bout-Roumazeilles, V.; Algeo, T.; Lyons, T.W.; Baudin, F. Paleodepositional conditions in the Orca Basin as inferred from organic matter and trace metal contents. Mar. Geol. 2012, 254, 62-72. [CrossRef]

44. Riquier, L.; Tribovillard, N.; Averbuch, O.; Devleeschouwer, X.; Riboulleau, A. The Late Frasnian Kellwasser horizons of the Harz Mountains (Germany): Two oxygen-deficient periods resulting from different mechanisms. Chem. Geol. 2006, 233, 137-155. [CrossRef]

45. Wignall, P.B. Black Shales; Oxford University Press: New York, NY, USA, 1994; pp. 23-24.

46. Calvert, S.E.; Pedersen, T.F.; Thunell, R.C. Geochemistry of the surface sediments of the Sulu and South China Seas. Mar. Geol. 1993, 114, 207-211, 217-231. [CrossRef]

47. Algeo, T.J.; Maynard, J.B. Trace-element behavior and redox facies in core shales of Upper Pennsylvanian Kansas-type cyclothems. Chem. Geol. 2004, 206, 289-318. [CrossRef]

48. Huested, E. Ocean anoxia and the concentrations of molybdenum and vanadium in seawater. Mar. Chem. 1991, 34, 177-196.

49. Schoepfer, S.D.; Shen, J.; Wei, H.; Tyson, R.V.; Ingall, E.; Algeo, T.J. Total organic carbon, organic phosphorus, and biogenic barium fluxes as proxies for paleomarine productivity. Earth-Sci. Rev. 2015, 149, 23-52. [CrossRef]

50. Xing, P.; Zwa, B.; Qla, B.; Jia, G.; Lza, B.; Wla, B. Sedimentary environments and mechanism of organic matter enrichment of dark shales with low TOC in the Mesoproterozoic Cuizhuang Formation of the Ordos Basin: Evidence from petrology, organic geochemistry, and major and trace elements. Sci. Direct Mar. Pet. Geol. 2020, 122, 104695.

51. Ibach, L.J. Relationship between sedimentation rate and total organic carbon content in ancient marine sediments. Am. Assoc. Pet. Geol. 1980, 66, 170-188.

52. Yan, D.; Wang, H.; Fu, Q.; Chen, Z.; He, J.; Gao, Z. Geochemical characteristics in the Longmaxi Formation (Early Silurian) of South China: Implications for organic matter accumulation. Mar. Pet. Geol. 2015, 65, 290-301. [CrossRef] 